\title{
Shortage in Access to Basic Social Services: A Case Study of Ethnic Minority Groups in Vietnam
}

\author{
Ha Thi Hai Do* Anh Ngoc Mai Nui Dang Nguyen \\ Faculty of Management Science, National Economics University, No. 207, Giai Phong Street, Dong Tam Ward, \\ Hai Ba Trung District, Hanoi, 11616, Vietnam
}

\begin{abstract}
The research uses shortages in the multi-dimensional poverty criteria and household living standards survey data collected by the General Statistic Office to evaluate the access to basic social services by ethnic minorities. The result shows significant differences in shortages between the Kinh and ethnic minorities, among ethnic minority groups and among localities. Differences in geographical location, level of development and lacking specific policies are the main causes. A number of policy recommendations has been made to narrow the gap in access to basic social services among ethnic minority groups in Vietnam.
\end{abstract}

Keywords: Ethnic minorities, basic social services, shortage in access to basic social services, Vietnam

DOI: $10.7176 / \mathrm{EJBM} / 12-17-15$

Publication date:June 30th 2020

\section{Introduction}

Along with impressive economic growth since Doi moi (renovation), which has put Vietnam into a country in the middle-income group since 2008, Vietnam also has achieved dramatic successes in poverty reduction. However, the number of people in poverty is still high in the mountains and uplands, where many ethnic minorities live. Ethnic minorities makeup about $14 \%$ of Vietnam's population but account for almost $50 \%$ of the poor in the country (Kozel, 2014).

Although the Government has issued and implemented many programs and projects to support ethnic minorities out of poverty, up to now, the ethnic minority regions are still the poorest region in the country. 9,604 over 48,494 (19.8\%) of the villages have not had concrete roads to the center of the commune/ward/town; more than 1,500 villages and hamlets have not used the national electric grid. Accessing to basic social services in the area is limited: (i) $1.9 \%$ of ethnic minority communes' schools are in a lack of solid or simple situation; $37.6 \%$ of ethnic minority groups' villages do not have cultural houses ... The quality of general education for ethnic minorities is low: up to $20.8 \%$ of ethnic minorities (in working age) cannot read and write; (ii) about $20.4 \%$ of commune health stations have not been standardized. The healthcare activities for people in remote and ethnic minority areas still face many difficulties (only $26.64 \%$ of ethnic minority women have regular prenatal checkups at least three times during pregnancy). The issuance of health insurance cards is not timely annually; name, age, and address are wrongly inputted in the health insurance card. There are significant obstacles in the process of using and settling medical examination and treatment expenses $(44.8 \%$ of ethnic minorities use health insurance cards for medical examination). On the other hand, severe transportation conditions, and lacking on-site means to transport patients significantly affect the results of treatment and emergency care for patients in remote communes and ethnic minority regions; (iii) After many years of implementing policies supporting housing, and productive land in the provinces, up to now, $15.3 \%$ of ethnic minority households live in temporary houses and $68.5 \%$ of ethnic minority households need more agricultural land; (iv) Deforestation, biodiversity reduction, and environmental pollution (soil, water, air) have not been controlled while the proportion of households using hygienic water (73.3\%) and assessing to hygienic latrines $(27.9 \%)$ is very low, especially in the provinces with a large amount of ethnic minorities in the Northern Uplands and the Highland; (v) The proportion of ethnic minority households with computers is $7.7 \%$, only $6.5 \%$ of them has internet connections. The proportion is relatively low compared to the national average (VLSS, 2015).

The situation of shortage in access to basic social services of ethnic minorities makes the poverty and repoverty of this group always at the highest level in the country. The poverty rate is much higher than the national average. Low educational level poses many risks of insecurity and political instability. In order to provide an overall picture of shortage in access to basic social services of ethnic minorities, the paper uses a set of indicators to measure deprivation according to national multi-dimensional poverty. The database for the study is from the General Statistics Office of Living Standards Survey (VLSS).

\section{Literature Review}

Components of social services such as education and health have been around for a long time to satisfy basic human needs. However, the concept of basic social services was introduced first time at the World Summit on Social Development in Copenhagen in May 1995 (OECD, 2006). The 20/20 Initiative defines basic social services as "service activities that provide pray for those who meet the minimum needs of life" comprising basic education, 
primary health care, and family planning services, low-cost water and sanitation, and nutrition programs ( UNDP, 2001).

The basic components of social services are not consistent in the research and practice of policy implementation in countries. Mehrotra, et al. (2000) confirmed the components of basic social services such as healthcare (healthcare for mothers during pregnancy; care and prevention of child malnutrition), basic education (primary school), clean water and housing would help people have opportunities to escape poverty and lead to a better life. Mehrotra (2006) argued that water and sanitation, basic education, basic healthcare, nutritional supplements for pregnant women and young children, and school lunches are components of basic social services. The State plays the most important role in providing these basic services. Studying the common benefits of social services in the European community, Polacek (2011) pointed out four components of basic social services that have the interest of member countries: (i) long-term healthcare, (ii) healthcare and education for children, (iii) employment services, and (iv) social housing. Těšín (2011) argued that for developing countries, basic social services include not only support for healthcare, food security, housing for target groups but also support for raising young children, accessing information and communicating with outside parties to ensure human rights and human interests. In South Korea during the period of President Park Chung Hee, the Saemaul Undong program focused on basic social services for rural people in order to improve the living conditions for this group of people with the goal "to make Rural is the dream of the city". Kim \& Kim (1977) pointed out the components of the basic social service system implemented during this period including (i) environmental improvement, (i) training to improve labor productivity in agriculture-forestry-fishery sector, (iii) housing welfare and healthcare for disadvantaged rural areas, (iv) childcare, (v) vocational training people in village regions.

In Vietnam, Nguyen Thi Lan Huong (2010) stated that basic social services consist of four main components: (i) services that meet basic physical needs: food, sanitation, care, housing; (ii) medical services including medical examination and treatment, convalescence and physical rehabilitation; (iii) educational services such as schools, training classes, life skills training, integrated, integrated and specialized forms of education; (iv) entertainment, participation and information services. The understanding of basic social services from the point of view above is limited to disadvantaged people; it is not of high universality. FitzGerald (2011), in the study of social services for human development in Vietnam, only deal with health and education issues. Yamazaki \& Phuoc (2011), when researching poverty among ethnic minorities in Vietnam, only focused on the access of the poor to health, education, and infrastructure issues.

The public policy system in Vietnam was mentioned about basic social services in the Vietnam National Action Program for Children 2001-2010 (Prime Minister, 2001 ${ }^{\mathrm{a}}$ ). Shortly thereafter, the National Target Program on poverty reduction and employment in 2001-2005 proposed the goal of supporting the poor, poor households and poor communes to access social services (Prime Minister, 2001 ${ }^{\mathrm{b}}$ ).

Access to basic social services is not only the goal of policies but also the criteria used to assess poverty in a multi-dimensional approach. The lack of opportunities, accompanied by malnutrition, illiteracy, illness, unhappiness and despair, are issues of interest in the concept of multi-dimensional poverty. Lack of economic, social or political participation and voice will push individuals, to the extent of being excluded, from enjoying socio-economic development benefits and thus being deprived of basic human rights (UN, 2012).

The international multi-dimensional Poverty Index, with three main dimensions: health, education, and living conditions, is now an important measure to complement the traditional poverty measurement method based on income (Alkire, S. \& Santos, 2010). Since 2015, Vietnam has also transformed its poverty line measurement from a unidimensional approach to a multi-dimensional approach, in which the level of shortages of access to basic social services in education, health, housing, clean water and sanitation, information is used as the evaluation criteria along with income criteria (Prime Minister, 2015).

The above concepts show high unity of nations, politicians, and scholars with the view of poverty that it is a multi-dimensional phenomenon, which needs to be recognized as lacking or unsatisfactory of the basic needs of the person. A lack of access to social services is a situation where people do not meet the minimum basic needs in life.

\section{Methodology}

This paper relies on data from the recent Vietnam Household Living Standard Survey in 2006, 2010, 2014, and 2018. These data were collected by the General Statistics Office of Vietnam (GSO). The 2006 - 2018 VHLSS covered 29,530 households. The samples are representative of the national and regional levels. The surveys gathered information through household and community level questionnaires. Information on households includes basic demography, ethnicity, education, health, housing, using clear water and environment service, accessing information assets. The VHLSSs allows for the analysis of shortage in accessing to households' basic social services. Besides, we will also use the locality government reports to compare shortage levels in access to basic social services between ethnic minority regions.

The main methods used in the report are descriptive statistics and graphics. Descriptive statistics is used to 
examine shortages in access of different people groups to basic social services. The method of comparison between ethnic minorities and the Kinh, between ethnic minority groups and between ethnic minorities among localities is used to make findings on the gap between these groups. This approach also helps to identify the factors affecting the lack of access to basic social services of ethnic minorities, such as differences in ethnicity and regions. Simple graphics are also used to provide virtual analysis.

The study used indicators to measure the level of deprivation in access to basic social services according to the multi-dimensional poverty line published by The Prime Minister (2015), including five dimensions of education, healthcare, housing, living conditions, access to information with ten indicators (see Table 1).

\begin{tabular}{|c|c|c|}
\hline $\begin{array}{l}\text { Basic Social } \\
\text { Services }\end{array}$ & Indicators & Degree of deficiency \\
\hline \multirow[t]{2}{*}{ Education } & Adult education & $\begin{array}{l}\text { Households with at least } 1 \text { member who ages } 15 \text { or older, born in } \\
1986 \text { to now and has not graduated from secondary but currently } \\
\text { not attending school }\end{array}$ \\
\hline & School attendance & $\begin{array}{l}\text { Households with at least } 1 \text { school-age children (5-14 years old) } \\
\text { but currently not attending school }\end{array}$ \\
\hline \multirow[t]{2}{*}{ Healthcare } & Access to health & $\begin{array}{l}\text { Households with ill members but do not have health examination } \\
\text { (illness is defined as being sick / injured so badly that they must } \\
\text { lie in one place. They must have another person to take care of. } \\
\text { They have to leave their job/study. They cannot participate in } \\
\text { normal activities) }\end{array}$ \\
\hline & Health insurance & $\begin{array}{l}\text { Households with at least } 1 \text { member who ages } 6 \text { or older, currently } \\
\text { does not have health insurance }\end{array}$ \\
\hline \multirow[b]{2}{*}{ Housing } & Housing quality & Households are in indecent or simple houses \\
\hline & Housing area & $\begin{array}{l}\text { (Housing is divided into } 4 \text { levels: permanent, semi-permanent, } \\
\text { indecent and simple). }\end{array}$ \\
\hline \multirow{2}{*}{$\begin{array}{l}\text { Clean water } \\
\text { and } \\
\text { sanitation }\end{array}$} & Safe water & The average housing area per capita is less than $8 \mathrm{~m} 2$ \\
\hline & Hygienic latrine & Households do not have access to hygienic water \\
\hline \multirow{2}{*}{$\begin{array}{l}\text { Access to } \\
\text { information }\end{array}$} & $\begin{array}{l}\text { Use of communication } \\
\text { services }\end{array}$ & Households do not use hygienic toilets \\
\hline & $\begin{array}{l}\text { Assets for access to } \\
\text { information }\end{array}$ & $\begin{array}{l}\text { Households without any members using telephone and the } \\
\text { internet }\end{array}$ \\
\hline
\end{tabular}

Source: The Prime Minister (2015)

\section{Research results}

Although there have been many advances in accessing basic social services of ethnic minorities, the level of deprivation is still significant in the indicators of water and sanitation. Except for adult education and access to information, the shortage in access to basic social services decreased during the period $2006-2018$. The health insurance index improved due to the fact that health insurance policies for the poor and ethnic minorities have been promoted significantly. The shortage of telecommunication services has decreased sharply due to the development of mobile phone production and internet service provision (Figure 1). 


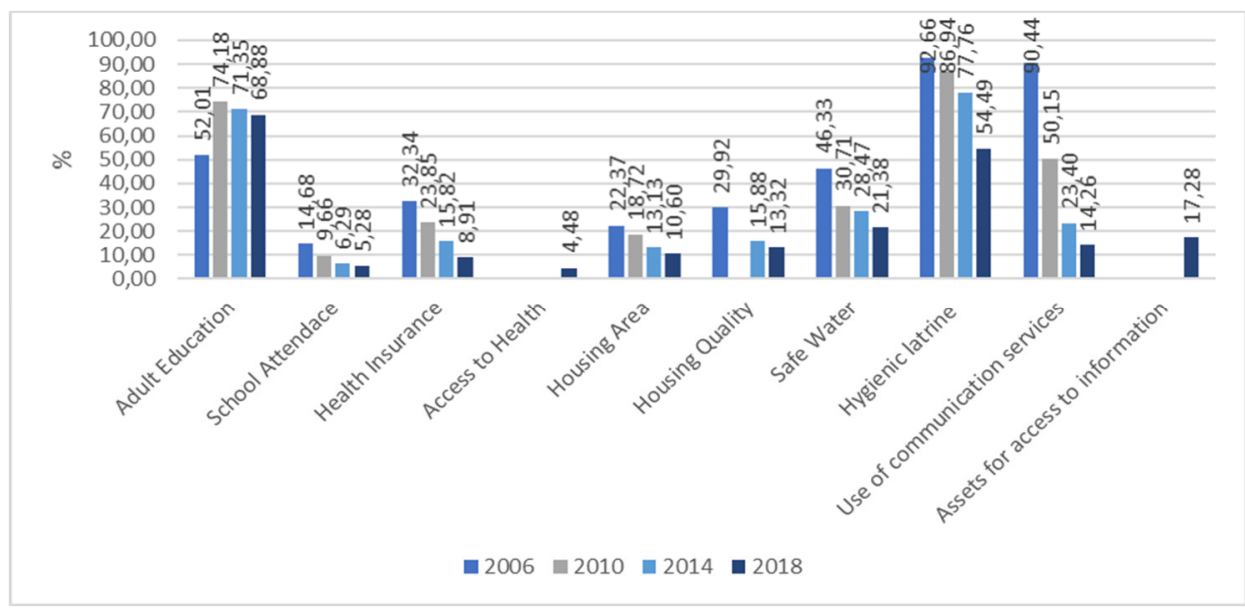

Figure 1: Proportion of ethnic minorities lacking basic social services (\%)

There is a significant difference in shortage in access to basic social services of ethnic minorities and the Kinh as well as the national average.

The shortage propotion varies significantly between ethnic minorities and the Kinh. Figure 2 shows that ethnic minorities have large gaps in almost all indicators reflecting access to basic social services. This represents a huge gap in access between the majority and the minority in society. However, the only bright spot is health insurance. The propotion of accessing to health insurance of The Kinh is much lower than that of ethnic minorities. The main reason is that free health insurance is provided for the poor and ethnic minorities.

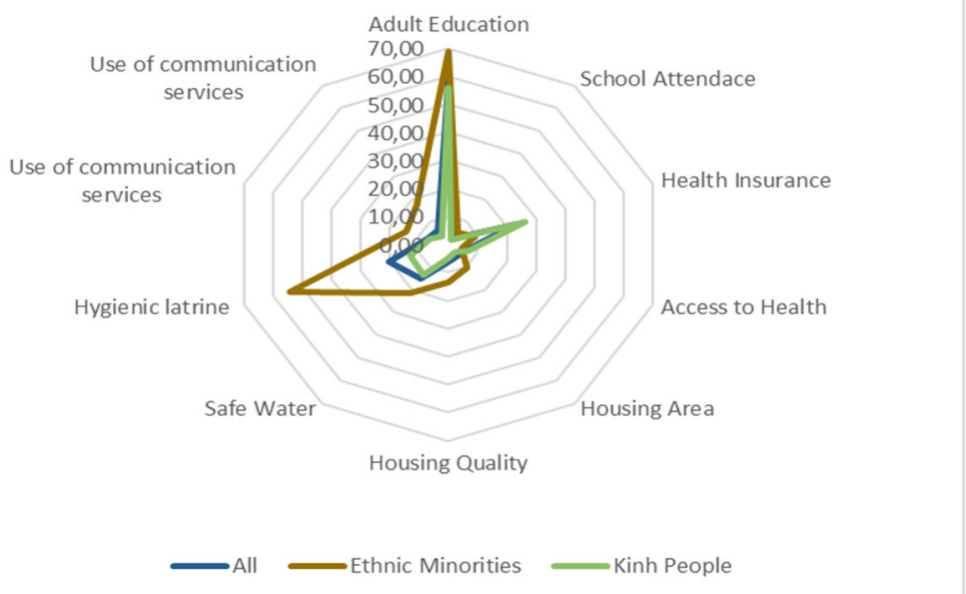

Figure 2: National average shortage of basic social services, 2018

The level of shortage in access to basic social services is also uneven among ethnic minorities.

Source: VHLSS

The Mong, Co, Xo Dang and Ra Glai ethnic groups have a higher level of deprivation in most of the basic social services than many other ethnic minorities and the Kinh. In contrast, ethnic minorities with a low level of basic social services are the Tay and the Thai. However, the shortage in access to health insurance by the Kinh is high among ethnic minorities, as the government provides free health insurance for ethnic minorities (Figure 3). 


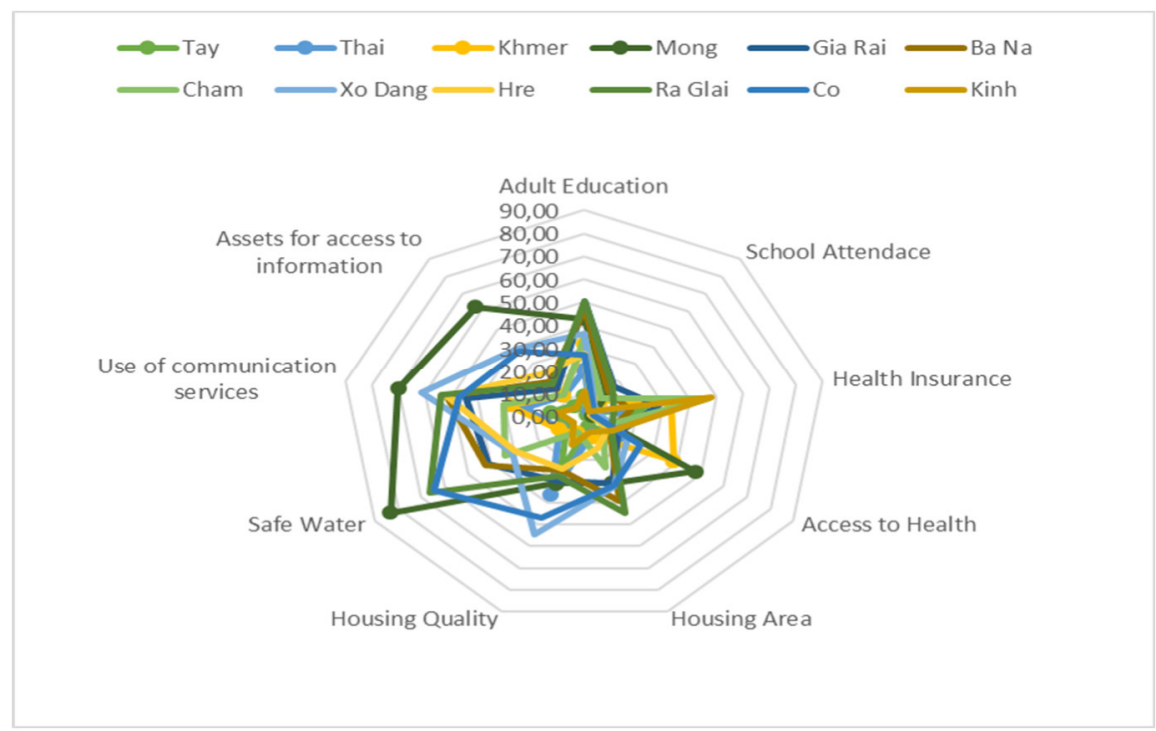

Figure 3: Deficiency rates of basic social services for ethnic minority groups, 2015

Source: Survey on the current socio-economic situation of 53 ethnic minority groups in 2015 Shortage access to basic social services is differentiated by geographic region.

Vietnam has very different geography among localities and regions. The level of access to social services is also different. The average rate of shortages is highest in Quang Ngai and the two provinces of the Central Highlands, in which Lao Cai has achieved very high efficiency in improving access to basic social services of ethnic minorities (Figure 4).

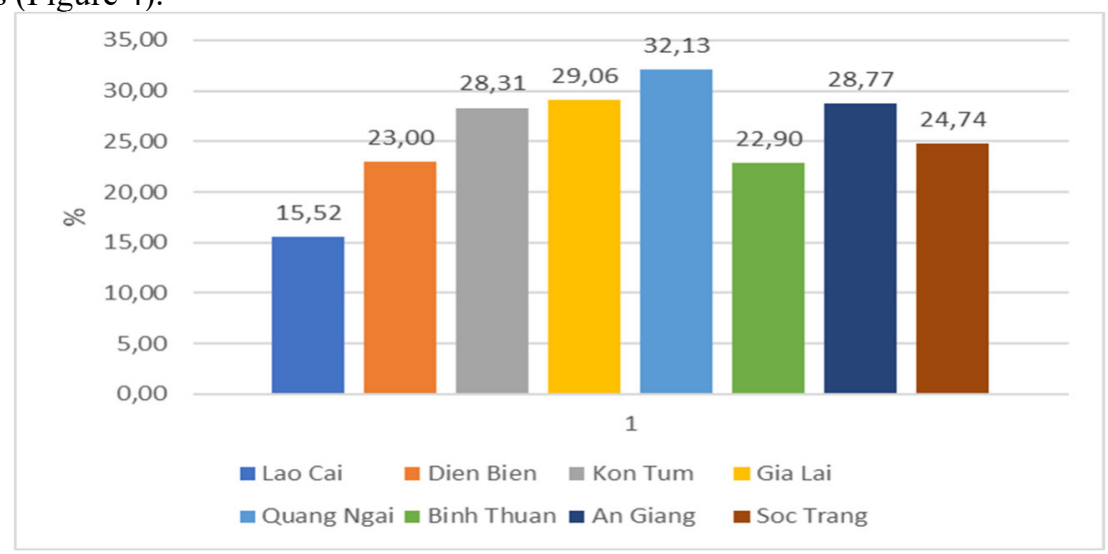

Figure 4: Average rate of social service shortage among ethnic minorities regions, 2018

Source: Local reports ${ }^{i}$

Differences in access between localities are reflected in all basic social services. However, the highest level of deprivation in localities still focuses on sanitation and housing services. On the other hand, access to health services and school attendance of children has significantly improved with relatively low levels of shortage (Figure $5)$. 


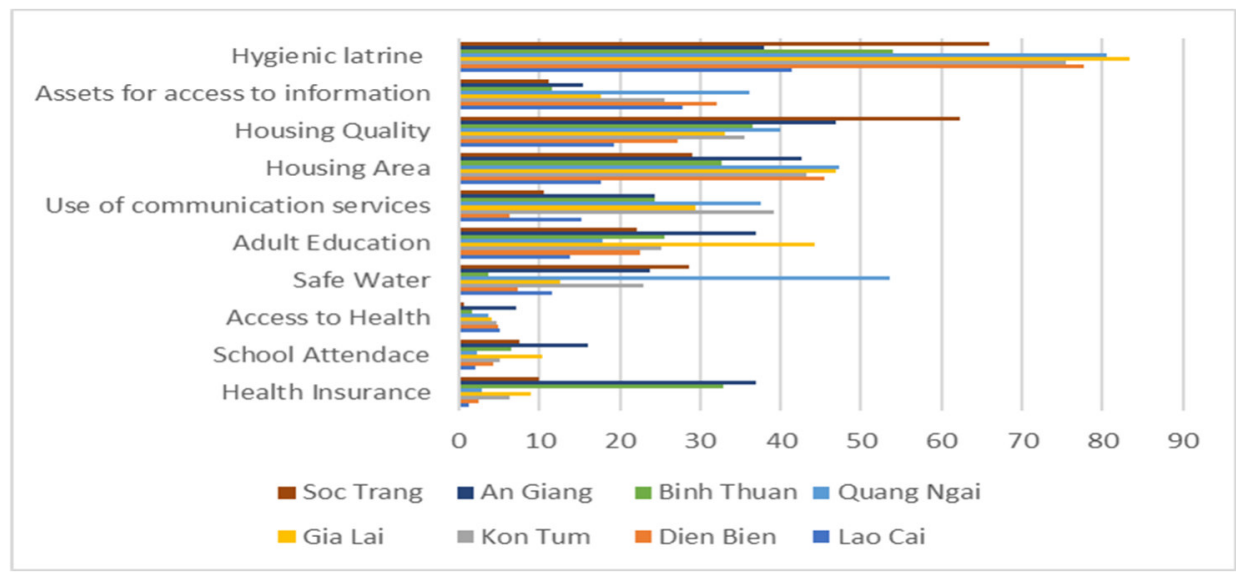

Figure 5: Degree of shortage of basic social services by ethnic minorities regions, 2018

Source: Local reports ${ }^{i}$

\section{Conclusions and recommendations}

There is a significant difference between ethnic minorities and the Kinh in terms of the level of shortage in access to basic social services, although supported by a number of state guarantees. However, the level of access of ethnic minorities is largely lower than the Kinh due to differences in geographical areas, natural conditions, educational level, income level, customs, and practices.

Ethnic minority groups in Vietnam have many similar characteristics, but there are also many differences in the level of deprivation in access to basic social services due to (i) different living areas and natural conditions (ethnic groups live in high mountains and remote areas normally have difficulties in accessing to infrastructures such as divided transportation, livelihoods based on forests and upland fields. Therefore, their socio-economic development faces more difficulties than ethnic minorities living in plains and lower regions); (ii) many policies on poverty reduction and support to access basic social services are designed in general, there is no specific policy system for each ethnic minority group; (iii) distintive intellectual levels, customs, and cultures of different ethnic groups (some still retain their own identities).

The findings of the study suggest some of the following policy recommendations as following:

Firstly, it is necessary to renovate the approach and formulate policies for ethnic minorities. Need to clearly define relationships, scope, contents of regional policies, comprehensive public policies, and specific policies for ethnic minority areas.

Second, legalize issues related to ethnic policies in the national legal system as an institutional basis to build policy systems for ethnic minorities. Also, the goals and targets that need to be achieved on access to basic social services for ethnic minorities also need to be reviewed, supplemented, and included in the system of legal documents.

Thirdly, to be able to orient ethnic policies in general and policies to ensure basic social services in particular in order to support the right people, according to the development level. There is a need to delineate ethnic minority areas according to development criteria. On that basis, build a system of continuous and regular information collection on ethnic minority areas to serve the planning and implementation of policies.

\section{Acknowledgment}

This research is a product of the CTDT.19.17/16-20 Project sponsored by the National Science and Technology Program from 2016 to 2020 "Basic and urgent issues on ethnic minorities and ethnic policy in Vietnam until 2030".

\section{References}

Alkire, S., \& Santos, M. E. (2010). Acute multi-dimensional poverty: A new index for developing countries. United Nations development program human development report office background paper, 2010/11.

Central Population and Housing Census Steering Committee (2019). Results of the Vietnam Population and Housing Census of 00:00 Hours on April 1 2019. Hanoi, Vietnam: Statistical Publishing House. ISBN: 978604-75-1448-9.

FitzGerald, I. (2011). Social Services for Human Development - Viet Nam Human Development Report. UNDP.

Kim, D. \& L. Kim (1977). Korea's Saemaul Undong: Social structure and the role of government in integrated rural development. Bulletin of the Population and Development Studies Center, 1-16.

Kozel, V. (Ed.). (2014). Well begun but not yet done: Progress and emerging challenges for poverty reduction in 
Vietnam. Washington, DC, USA: The World Bank. ISBN: 978-1-4648-0006-1. DOI: 10.1596/978-1-46480006-1

Mehrotra, S. (2006). Governance and basic social services: Ensuring accountability in service delivery through deep democratic decentralization. Journal of International Development, 18, 263-283.

Mehrotra, S., Vandemoortele, J., \& Delamonica, E. (2000). Basic Services for All? Public Spending and the Social Dimensions of Poverty. Florence, Italy: UNICEF Innocenti Research Centre.

Nguyen Thi Lan Huong (2010). Assess the status of social services for workers and disadvantaged groups in the social security policy framework. Cooperation program between the Ministry of Labor, Invalids, and Social Affairs MOLISA) - Spanish Agency for Development and Cooperation (AECI).

OECD (2006). Creditor Reporting System on Aid Activities 2006: Aid Activities for Basic Social Services in 2004. Paris, France: OECD Publishing. ISBN: 978-9-2640-2855-5. DOI: https://doi.org/10.1787/9789264028555en-fr.

Polacek, R. (2011). Study on social services of general interest. Study on Social Services of General Interest DG for Employment, Social Affairs, and Inclusion, European Commission.

Těšín, Č. (2011). Social services in the Czech Republic. Challenges for practice, theory and policy. International Academic for Diaconia and Social action and Central and Eastern Europe, Palgrave Macmillan

The Prime Minister (2001 a). Decision No. 23/2001/QĐ-TTg Ratifying the Vietnam National Program of Action for Childern in the 2001-2010 Period. Hanoi, Vietnam. Issued on February 26, 2001.

The Prime Minister $\left(2001^{\mathrm{b}}\right)$. Decision No. 143/2001/QĐ-TTg Approving the National Target Program on Hunger Elimination, Poverty Alleviation and Employment in the 2001 - 2005 Period. Hanoi, Vietnam. Issued on September 27, 2001.

The Prime Minister (2015). Decision No. 59/2015/QD-TTg promulgating multi-dimensional poverty levels applicable during 2016-2020. Hanoi, Vietnam. Issued on November 19, 2015.

UN (2012). The Millennium Development Goals Report 2012. New York, USA: the United Nations. ISBN: 978-92-1101258-3.

UNDP (2001). Choices for the Poor: Lessons from national poverty strategies. New York, USA: United Nations Publications. ISBN-13: 978-9211261387

Yamazaki, S. and Phuoc, H. S. (2011). Poverty of Ethnic Minorities in Viet Nam: Situation and Challenges in Programme 135 Phase II Communes, 2006-2007. United Nations Development Programme in Viet Nam and Committee for Ethnic Minority Affairs (CEMA).

${ }^{\mathrm{i}}$ Reports of localities comply with the content of Official Letter No. 3187 / VPQH-GS dated December 3, 2018 of the National Assembly's Office on reporting the implementation of policies and laws on the implementation of the National Target Program - Sustainable poverty reduction in ethnic minority and mountainous areas in the period of $2012-2018$ 